\title{
Novel Trends in Electrochemical Biosensors for Early Diagnosis of Alzheimer's Disease
}

\author{
Pavla Valkova and Miroslav Pohanka \\ Department of Molecular Pathology and Biology, Faculty of Military Health Science, University of Defense, Trebesska 1575, \\ 50011 Hradec Kralove, Czech Republic
}

Correspondence should be addressed to Miroslav Pohanka; miroslav.pohanka@gmail.com

Received 16 March 2021; Accepted 26 August 2021; Published 2 September 2021

Academic Editor: Kevin Honeychurch

Copyright (c) 2021 Pavla Valkova and Miroslav Pohanka. This is an open access article distributed under the Creative Commons Attribution License, which permits unrestricted use, distribution, and reproduction in any medium, provided the original work is properly cited.

\begin{abstract}
Background. Alzheimer's disease (AD) is a multifactorial progressive and irreversible neurodegenerative disorder affecting mainly the population over 65 years of age. It is becoming a global health and socioeconomic problem, and the current number of patients reaching 30-50 million people will be three times higher over the next thirty years. Objective. Late diagnosis caused by decades of the asymptomatic phase and invasive and cost-demanding diagnosis are problems that make the whole situation worse. Electrochemical biosensors could be the right tool for less invasive and inexpensive early diagnosis helping to reduce spend sources - both money and time. Method. This review is a survey of the latest advances in the design of electrochemical biosensors for the early diagnosis of Alzheimer's disease. Biosensors are divided according to target biomarkers. Conclusion. Standard laboratory methodology could be improved by analyzing a combination of currently estimated markers along with neurotransmitters and genetic markers from blood samples, which make the test for AD diagnosis available to the wide public.
\end{abstract}

\section{Introduction}

Biosensors are simple but very precise analytical devices suitable for the detection of a broad spectrum of biological and chemical analytes. They are based on the conversion of a biological or chemical reaction into a measurable signal. Their application increases over years to medical, environmental, industrial, food, or pharmaceutical analysis mainly due to their fast response, accuracy, low cost, portability, and suitability for the point-of-care diagnosis $[1,2]$. The history of biosensors dates back to the 1960s when Clark and Lyons presented the first biosensor. It was based on an oxygen electrode, so the first electrochemical biosensor was described [2, 3]. Many new biosensor designs are currently known. We can divide them either by their detection technique (called a physicochemical transducer) into magnetic, optical, electrochemical, mass-based, and thermal or by their biorecognition element, which is a biomolecule bound to the surface of the transducer. Enzymes, antibodies, genetic material (DNA, RNA), or whole cells and tissues are usually used as a biorecognition element. The biorecognition element provides a specific catalytic or binding reaction to the analyte, which is directly converted to a measurable signal by the transducer on its surface [4].

Alzheimer's disease (AD) is a neurodegenerative disorder characterized by an irreversible and progressive loss of selectively vulnerable populations of neurons [5, 6]. AD is an incurable devastating disorder that mainly affects the elderly population; it is currently estimated that more than 30 million people have $\mathrm{AD}$, and their number is growing rapidly. Fast response to the first symptoms of $\mathrm{AD}$ is the key factor in the diagnosis of early stages of the disease, so treatment can be initiated and quality of life extended. Standard tests for $\mathrm{AD}$, including magnetic resonance imagining, positron emission tomography (PET), near-infrared, or cerebrospinal fluid (CSF) analysis, are invasive and expensive and are usually performed on patients with the development of mild cognitive impairment. Thus, the lowcost test appropriate for the diagnosis of all stages of $\mathrm{AD}$ is required, and electrochemical biosensors represent a 
promising alternative for currently available diagnostic techniques [2, 7].

\section{Electrochemical Biosensors}

Interest in electrochemical biosensors has increased over the years, mainly due to their high sensitivity, simple construction, easy handling, portability, low cost, ability to measure turbid samples, and compatibility, unlike the other types of biosensors [8, 9]. Electrochemical biosensors are based on the transformation of a biochemical signal into an amperometric signal while electrons are either generated or used. The amperometric signal is created by a potentiometric, amperometric, conductometric, or impedimetric transducer $[3,10]$. The type of electrochemical sensor depends on the measured parameter: the electrical current is measured by the amperometric transducer, the generated potential is measured by the potentiometric transducer, conductance of medium is measured by the conductometric transducer, and impedance of medium is measured by impedimetric transducer [8]. Measured parameters of different electrochemical transducers are shown in Figure 1.

Amperometric biosensors are among the very simple detection techniques gaining interest in many scientific fields. The current resulting from the oxidation or reduction of electroactive substance is measured using a constant potential [11, 12]. Voltammetry is a method covered by amperometric techniques, but the varying potential is applied to the working electrode, and the change of current is observed [13]. Voltammetric techniques, including cyclic voltammetry, square wave voltammetry, differential pulse voltammetry, or linear sweep voltammetry, are often used in the construction of electrochemical biosensors [14]. Potentiometric biosensors are based on measuring potential/ $\mathrm{pH}$ variation as a response to applied current, usually with low amplitude. It is often used in food, environmental, and clinical analysis to measure many organic and inorganic substances. The simplest potentiometric sensor is a $\mathrm{pH}$ or any other ion-selective electrode $[15,16]$. Conductometric biosensors interpret a specific biological reaction on the transducer's surface as electrical conductance measured using a low-amplitude alternating electrical potential. The conductivity of sample change relies on the production or consumption of charged species [16, 17]. Impedimetric biosensors measure changes in impedance as a frequency function. Impedance is like resistance opposite of current flow, but resistance occurs in a direct current circuit, while impedance occurs in full alternating current circuits. Impedimetric biosensors usually determine affinity interactions between molecules [18, 19]. The pros and cons of different electrochemical techniques are summarized in Table 1.

The electrochemical biosensors can also be divided into two groups regarding the electrochemical recognition process: biocatalytic sensors and bioaffinity sensors. The biocatalytic sensors are characterized by a catalytic reaction taking place on the surface of sensors and enzymes while the cells and tissues are appropriate biorecognition elements enabling this kind of reaction. On the other hand, bioaffinity sensors are typical for the affinity interaction taking place on the electrode surface, such as antigen-antibody interaction, nucleic acids interaction, or aptamer interaction. The bioaffinity biosensors with electrochemical detection are evolving rapidly because of their simplicity, low time, and high sensitivity, in contrast to traditional techniques for the detection of DNA, RNA, or antibodies such as polymerase chain reaction or fluorescence in situ hybridization. Their application in the diagnosis of AD is in great demand [7]. Biomolecules appropriate as biorecognition elements in electrochemical biosensors are shown in Figure 2.

\section{Alzheimer's Disease}

$\mathrm{AD}$ is currently one of the most common forms of dementia. According to the World Health Organization, any type of dementia affects around 50 million of people worldwide and AD suffers to $60-70 \%$ of them [20]. According to the current estimates, the number of patients with $\mathrm{AD}$ will increase to more than 100 million by 2050 . AD is thus becoming a global health and socioeconomic problem, due to the cost and time-demand of treatment [2, 5, 7]. AD characterized as progressive and irreversible decay of cognitive functions was first described in 1907 by German neurologist Alois Alzheimer. Typically, the memory and time and space orientation of older people are affected. People under the age of 65 years are susceptible rarely, only $4-6 \%$ of cases involve people younger than 65 years, and the early onset of $\mathrm{AD}$ is typically associated with genetic mutation [2, 21, 22]. $\mathrm{Pa}-$ tients are affected by more dramatic multidomain cognitive impairment involving memory, attention, language, and visuospatial and executive behavior. The prodromal phase of $\mathrm{AD}$ dementia rarely precedes, and a faster progression to a severe condition is observed [23]. AD is a multifactorial disease characterized by extracellular deposition of amyloid $\beta$ (A $\beta$ ) peptides forming senile plaques by intraneuronal neurofibrillary tangles (NFT) of hyperphosphorylated tau protein and substantial synaptic and neuronal loss. Amyloid angiopathy is also common. The hippocampus, amygdala, entorhinal cortex, and cortical association areas belong to the most affected brain areas $[2,6,24]$. Aggregation of $A \beta$ is possibly accelerated by chelation with metal ion mainly $\mathrm{Cu}^{\mathrm{II}}$ and $\mathrm{Fe}^{\mathrm{III}}[25,26]$. The etiology of $\mathrm{AD}$ is still unclear, and the probable pathological thesis is summarized in Figure 3 $[24,27,28]$.

The first changes in the brain begin years, even decades, before symptoms appear. This phase is called the pathophysiological or clinical stage, and it is characterized as an asymptomatic period no different from normal aging. $\mathrm{A} \beta$ is deposited in neocortical areas of the brain without cognitive or behavioral changes. On the other hand, it is still not clear whether all $\mathrm{A} \beta$ deposition leads to the development of $\mathrm{AD}$. The diagnostic methodology for this phase has not been established. The National Institute on Aging and the Alzheimer's Association focused on the design of diagnostic criteria and biomarkers appropriate for the diagnosis of early $\mathrm{AD}$ stages $[5,7,29,30]$. The prodromal stage of $\mathrm{AD}$ known as mild cognitive impairment (MCI) is the period between normal aging and $\mathrm{AD}$, and patients are cognitively impaired, 

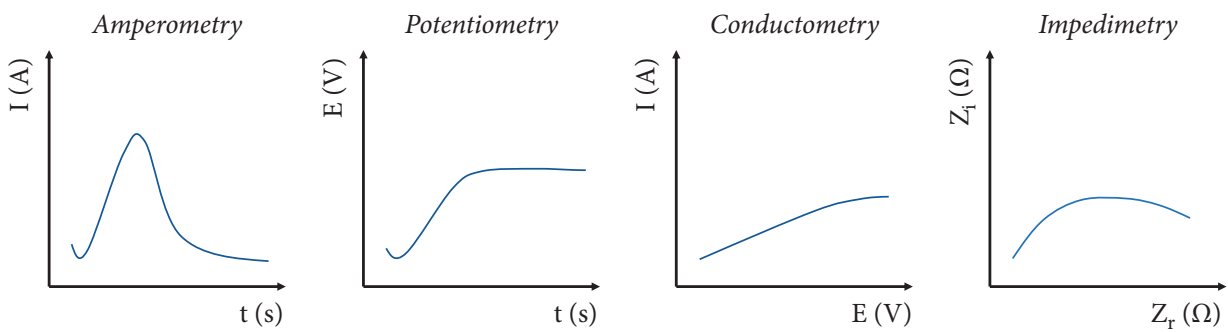

FIGURE 1: Division of electrochemical transducers according to the measured parameter and graphs of resulting curves.

TABLE 1: Summary of advantages and disadvantages of various electrochemical techniques.

\begin{tabular}{|c|c|c|}
\hline $\begin{array}{l}\text { Electrochemical } \\
\text { technique }\end{array}$ & Advantages & Disadvantages \\
\hline Amperometry & Fastness, sensitivity, precision & Poor selectivity \\
\hline Potentiometry & Measuring of low concentration and turbid samples & $\begin{array}{l}\text { Possibility of false-negative result } \\
\text { by strong buffers }\end{array}$ \\
\hline Conductometry & $\begin{array}{c}\text { Use in living biological system } \\
\text { No reference electrode needed easy miniaturization; they measure both } \\
\text { electroactive and inactive analytes }\end{array}$ & Low specificity \\
\hline Impedimetry & $\begin{array}{l}\text { Possibility of label-free setup; they can be applied in living biological system } \\
\text { and they exert high sensitivity and suitability for miniaturization }\end{array}$ & Poor selectivity \\
\hline
\end{tabular}

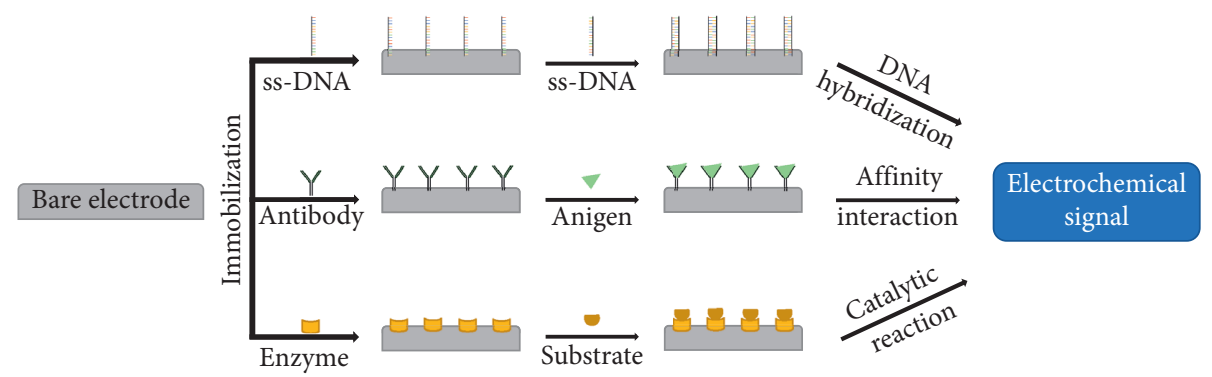

Figure 2: Biomolecules commonly used in the construction of electrochemical biosensors.

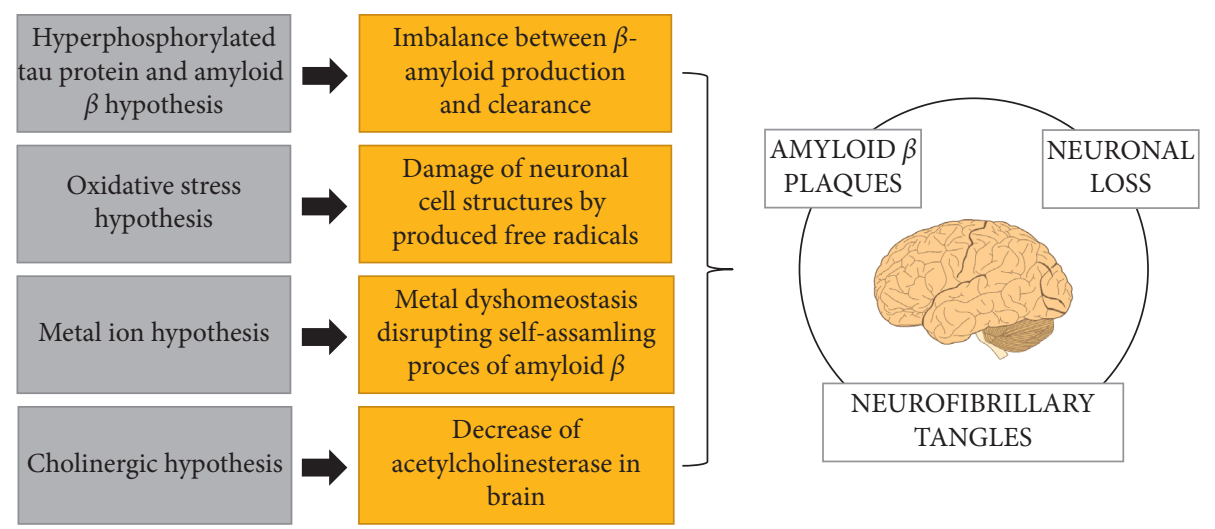

Figure 3: Hypothesis of $\mathrm{AD}$ pathology leading to $\mathrm{A} \beta$ plaques formation, formation of NFT of hyperphosphorylated tau protein, and neuronal loss.

usually in memory but not demented. Cognitive functions such as orientation, language, attention, and executive function may also be affected, and patients may have mild problems to easily perform common daily tasks. Patients suffering MCI have an increased risk of developing $\mathrm{AD}$, so MCI treatment aims to reduce this risk [5, 31-33]. The third phase, called AD dementia, is characterized as a slow progression of memory disturbance followed by other cognitive domains' disturbance (language, social, and occupational dysfunctions) and behavioral changes. Plaques of deposited $\mathrm{A} \beta$ and NFT are the main pathological features of this stage $[5,31]$. Three neuroimaging markers were established for the 
diagnosis of Alzheimer's disease: magnetic resonance imagining (MRI) of hippocampal atrophy, fluorodeoxyglucose PET (FDG-PET) of temporoparietal hypometabolism, and PET of increased brain deposition of $\mathrm{A} \beta$ and NFT [23].

The individual phases are overviewed in Table 2.

\section{Alzheimer's Disease Biomarkers}

4.1. CSF Biomarkers. The analysis of CSF biomarkers, reliable indicators of cerebral neurochemistry, is an established diagnostic method achieving high specificity in the diagnosis of $\mathrm{AD}$ (survey in Figure 4). CSF biomarkers are perfect as diagnostic criteria for the early stages of $\mathrm{AD}$. On the other hand, obtaining CSF is an invasive and painful procedure with possible side effects, especially in the elderly. CSF analysis is performed either immunohistochemically or by enzyme-linked immunosorbent assay. Both methods are relatively expensive and time consuming. To date, three biomarkers have been established for the diagnosis of $\mathrm{AD}$ from CSF: phosphorylated tau protein (P-tau) 181, total tau protein (T-tau), and $\mathrm{A} \beta[2,7,10]$. Decreased $\mathrm{A} \beta_{42}$ alone or in combination with $\mathrm{A} \beta_{40}$ and increased $\mathrm{P}-\operatorname{tau}_{181}$ and T-tau is a typical profile for the diagnosis of AD from CSF [34]. The analysis of these three CSF biomarkers has high diagnostic accuracy (85-90\%) in the diagnosis of AD and also in the diagnosis of MCI, so they have been incorporated in the diagnostic criteria of $\mathrm{AD}[35]$.

4.1.1. $P$-tau 181 and T-tau. Tau protein is a microtubuleassociated protein that normally stabilizes microtubules in the cell cytoskeleton, but it is also forming intracellular aggregates in several neurodegenerative diseases including AD. Phosphorylation of tau protein is a physiological process ensuring regulation of tau protein production. Under pathological conditions, the tau protein becomes hyperphosphorylated and causes protein separation from the microtubules and destabilizes them structurally, so axonal transport is disrupted. Hyperphosphorylated tau protein forms masses of paired helical filaments inside the nerve cell bodies - the NFT, one of the clinical criteria for AD diagnosis [10, 36, 37]. Thus, tau protein has become a biomarker evaluated in the $\mathrm{AD}$ diagnosis as a sign of axonal degeneration and NFT formation. However, the tau protein exists in the human brain in 6 isoforms produced from a single gene that differ in posttranslational modification including phosphorylation, glycosylation, and oxidation. The tau protein isoform phosphorylated on threonine 181 $\left(\mathrm{P}-\operatorname{tau}_{181}\right)$ is important for $\mathrm{AD}$ diagnosis. While the $\mathrm{P}-\mathrm{tau}_{181}$ may be a more specific marker of $\mathrm{AD}$, general $\mathrm{T}$-tau belongs to general CSF markers of all neurodegeneration, so, elevated levels of T-tau may be also detected in other tauopathies. This is due to the NFT structure, typical for AD, which consists of hyperphosphorylated tau protein $[10,34,37,38]$.

4.1.2. $A \beta_{42}$ and $A \beta_{40}$. Any imbalance in the production or clearance of amyloidogenic $\mathrm{A} \beta$ peptides leads to extraneuronal accumulation of $\mathrm{A} \beta$ in amyloid plaques, the second well-documented pathology of $\mathrm{AD}$, and also the second clinical diagnostic criteria of $\mathrm{AD}$. $\mathrm{A} \beta$ peptides, normally soluble, exist in many conformations consisting of 36-43 amino acids, so they are labeled according to the length of their amino acid chain. In particular, $\mathrm{A} \beta_{42}$ most easily succumb to aggregation into $A \beta$ plaques. $A \beta_{42}$ and $\mathrm{A} \beta_{40}$ are the most reliable indicators of $\mathrm{AD}$. Compared to the healthy population, the analysis of $\mathrm{A} \beta_{42}$ from CSF in $\mathrm{AD}$ patients shows a substantial decrease, probably caused by its aggregation into plaques. On the other hand, $\mathrm{A} \beta_{40} \mathrm{CSF}$ levels do not correlate with $\mathrm{AD}$ status, the levels are not decreased, and it is not formed in amyloid plaques. Despite this fact, its levels are measured in the diagnosis of $\mathrm{AD}$, given that the ratio $\mathrm{A} \beta_{42} / \mathrm{A} \beta_{40}$ shows a significant decrease. The analysis of ratio $\mathrm{A} \beta_{42} / \mathrm{A} \beta_{40}$ has a more corresponding value than the measurement of $\mathrm{A} \beta_{42}$ alone, as it compensates for intraindividual changes within $\mathrm{AD}$ patients and has a better association with the pathogenesis of $\mathrm{AD}[7,30,36]$.

4.1.3. Neurotransmitters. Neurotransmitters are endogenous chemical compounds that act as communication messengers between neurons. To date, more than a hundred neurotransmitters have been discovered [9]. AD is not a disease affecting only the cognitive functions of the brain, but noncognitive symptoms have been observed, including agitation, anxiety, depression, apathy, psychosis, and sleep or appetite disorders. Various studies suggested that neurotransmitters have a key role in both cognitive and behavioral dysfunctions of $\mathrm{AD}$ [39]. Neurotransmitters including acetylcholine, dopamine, serotonin, glutamate, and norepinephrine have been studied as factors influencing the development of neurodegeneration and as possible biomarkers of early stages of $\mathrm{AD}[7,40]$.

4.2. Blood Biomarkers. So far, the analysis of CSF and neuroimaging, mainly PET scan, has the dominant role in $\mathrm{AD}$ diagnosis as well as in $\mathrm{AD}$ drug design. Although the analysis of biomarkers from CSF in the diagnosis of $\mathrm{AD}$ is a specific and established method with high diagnostic accuracy, it is still an invasive intervention in the body. In recent years, therefore, there has been a growing tendency to establish a methodology for the diagnosis of $\mathrm{AD}$ from plasma samples $[2,41]$. Possible problems when using blood samples to measure AD biomarkers could be high interferences and the ability of the biomarker to penetrate from CSF to blood through the blood brain barrier [30]. The following biomarkers described below including APOE 4, protein $\mathrm{p} 53$, and the other proteins are very often also CSF biomarkers (8 Toyos-Rodriguez 2020). A survey of the most promising blood biomarkers is given in Figure 5.

4.2.1. $A \beta$ and Tau. Initial studies did not suggest a relevant correlation between CSF and blood levels of $\mathrm{A} \beta_{42}$ or ratio $\mathrm{A} \beta_{42} / \mathrm{A} \beta_{40}$, as was summarized in the meta-analysis of Olsson and coauthors (2016) [35]. On the other hand, new studies showed promising results in the analysis of $\mathrm{A} \beta$ from 
TABLE 2: Overview of AD phases [5, 10, 30-32].

\begin{tabular}{lccc}
\hline Phase & Symptoms & Neuroimaging & Biomarkers \\
\hline Clinical & None & None & None \\
MCI & $\begin{array}{c}\text { Change of cognitive ability } \\
\text { Impairment of at least one cognitive domain }\end{array}$ & MRI, PET, FDG-PET & CSF levels of T-tau, P-tau, and A $\beta_{42}$ \\
AD dementia & $\begin{array}{c}\text { Mild problems in performing complex tasks not demented } \\
\text { Cognitive and behavioral dysfunctions }\end{array}$ & MRI, PET, FDG-PET & CSF levels of T-tau, P-tau, and A $\beta_{42}$ \\
\hline
\end{tabular}

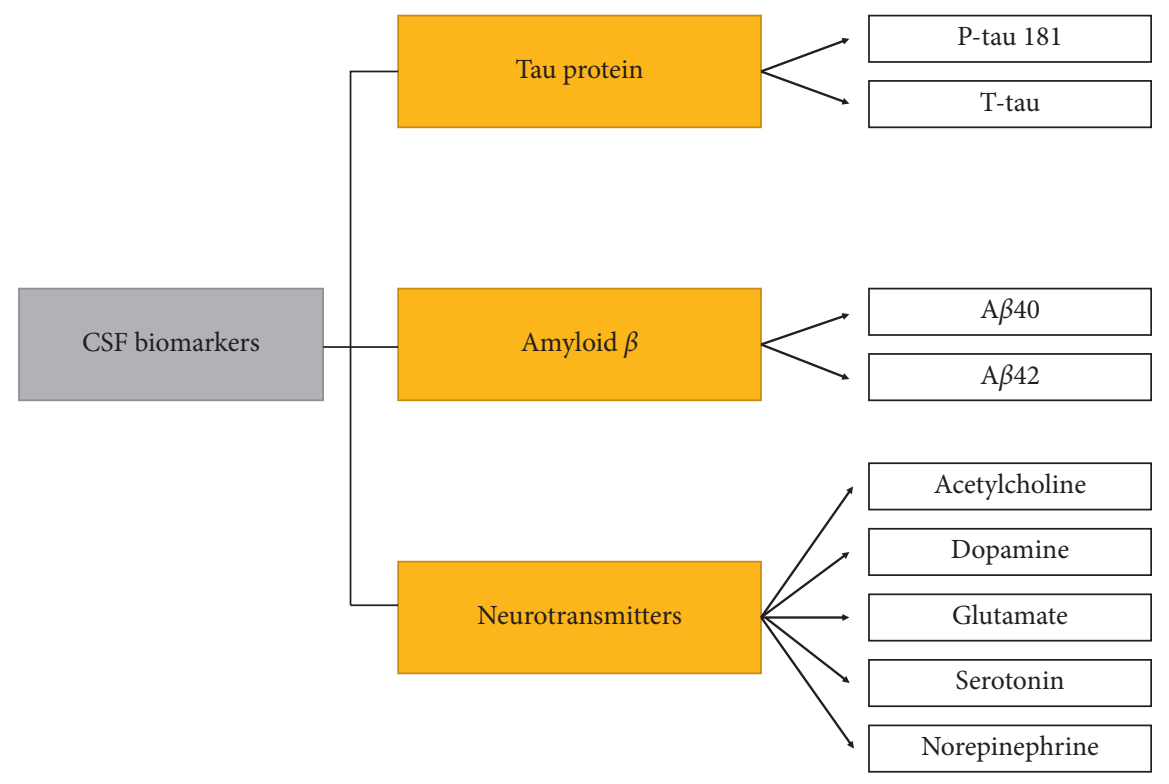

Figure 4: Overview of the most common CSF biomarkers.

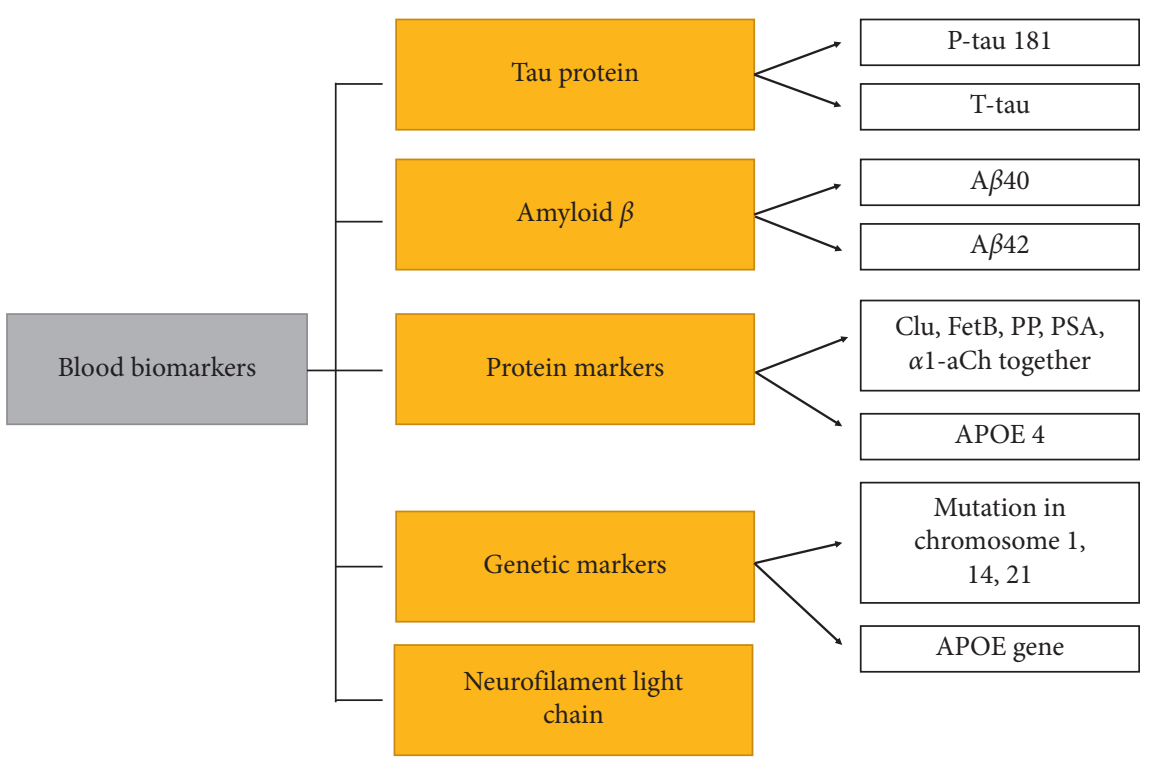

FIGURE 5: Overview of the most promising blood biomarkers. Clu: clusterin; FetB: fetuin B; PP: pancreatic prohormone; PSA: prostatespecific antigen; $\alpha 1$-aCh: $\alpha 1$-antichymotrypsin.

blood. In the work of Janelidze and coauthors (2016), a weak positive correlation between CSF and blood levels for both $\mathrm{A} \beta_{42}$ and $\mathrm{A} \beta_{40}$ was observed mainly in patients with $\mathrm{AD}$ dementia. Prodromal stages showed just a moderate decrease in $\mathrm{A} \beta_{42}$ levels and no decrease in $\mathrm{A} \beta_{40}$ levels. This work reveals that plasma changes of $A \beta$ levels occur much later in comparison with the levels of $A \beta$ in CSF [42]. The possibility of $\mathrm{A} \beta$ measurement was also studied in the work of Ovod and coauthors (2017) and Nakamura and coauthors (2018) with a proven correlation between $\mathrm{A} \beta$ levels in the 
blood and CSF $[41,43,44]$. Regarding the measurement of plasma T-tau and P-tau, the work of Toombs and Zetterger (2020) mentioned a contrast result from various studies. It probably depends on the sensitivity of the chosen method. Using ultrasensitive assays, plasma tau levels were increased compared to the healthy population, but this increase is negligible in comparison with levels of tau from CSF. On the other hand, increased plasma levels of $\mathrm{P}-\mathrm{tau}_{181}$ correlate perfectly with increased CSF levels of P-tau ${ }_{181}[41,45]$.

4.2.2. Neurofilament Light Chain. The neurofilament light chain is an intraaxonal structural protein that leaks into body fluids, both CSF and blood, during axonal damage, regardless of the cause. Although it is not clear how blood levels of NFL correlate with neurodegeneration, it belongs to the most consistent plasma biomarkers of neurodegeneration $[41,45]$.

4.2.3. Protein Markers. Plasma levels of proteins including clusterin, fetuin B, pancreatic prohormone, and prostatespecific antigen complexed to $\alpha 1$-antichymotrypsin are altered during $\mathrm{AD}$ and can be analyzed as good biomarkers but only together represent a reliable tool for diagnosis with strong correlation to AD [2]. Apolipoprotein E4 (APOE4) is considered a risk factor for the development of $\mathrm{AD}$ and has been introduced as a plasma biomarker for early diagnosis of $\mathrm{AD}$. APOE is a glycoprotein that mediates the binding of lipoproteins to their low-density receptors. They are predominantly expressed in the brain in several isoforms, APOE2, APOE3, and APOE4 belong to the most common ones, but only APOE4 presents a risk factor to AD by reducing amyloid clearance and accelerating senile plaques formation. Circa $50 \%$ of all AD patients have APOE 4 isoform $[7,10]$. The protein p53 responds to cellular stress, and the relationship between conformationally altered p53 and $\mathrm{AD}$ diagnosis in blood has been studied since 2008 when Lanni and coauthors observed unfold p53 in peripheral blood cells of $\mathrm{AD}$ patients. Recently, unfolded protein p53 was determined from blood in the work of Amor-Gutiérrez and coauthors (2020) using a competitive electrochemical immunosensor with promising results $[46,47]$.

4.2.4. Genetic Markers. The AD, not only early-onset type, can be diagnosed by the analysis of the genome of patients. Genetic mutations and polymorphisms related to the disease can be discovered. Single gene mutation of chromosomes 1, 14 , and 21 causes malformations on amyloid precursor protein, presenilin 1 , and presenilin 2 , and it is the cause of the early onset of $\mathrm{AD}$. The above-mentioned polymorphism of APOE is the probable most common genetic cause of late onset of $\mathrm{AD}$ and can be also revealed by the analysis of the genetic material [2].

4.2.5. Metals. Metals, including $\mathrm{Cu}^{\mathrm{II}}, \mathrm{Zn}^{\mathrm{II}}$, and $\mathrm{Fe}^{\mathrm{III}}$, may play an important role in $\mathrm{AD}$ pathology due to their high concentration in senile plaques. Mainly redox-active metals $(\mathrm{Cu}$ and $\mathrm{Fe})$ are able to bound on $\mathrm{A} \beta$, stabilize its oligomeric form, and accelerate the aggregation of $\mathrm{A} \beta[25,26]$. Recently, altered plasma metal levels were observed in conditions involving CNS-associated disorders in the work of Nahan and coauthors (2017). According to the work of $\mathrm{Xu}$ and coauthors (2018) and Guan and coauthors (2017), plasma metals are suggested as potential blood markers [48-50].

\section{Electrochemical Biosensors in Diagnosis of Alzheimer's Disease}

5.1. Detection of $A \beta$. In recent years, highly sensitive electrochemical biosensors have been designed for the detection of $\mathrm{A} \beta$, especially $\mathrm{A} \beta_{42}$ and $\mathrm{A} \beta$ oligomers. With respect to the type of biorecognition element, three main groups of structures were used: RNA aptamer, antibody, and molecularly imprinted polymers (MIP). The developed biosensor devices are typically portable and simple tools commonly suitable for point-of-care use when a commercial product based on the research will be introduced into the market.

In the work of Negahdary and Heli (2019), RNA aptamer was immobilized onto the surface of gold disk electrode with electrodeposited fern leaves-like gold nanostructure intended to detect $\mathrm{A} \beta_{42}$ [51].

MIP has also been used in the work of Ozcan and coauthors (2020) and Pereira and coauthors (2020), both aimed to detect $\mathrm{A} \beta_{42}[52,53]$. The classic electrochemical biosensor construction, a glassy carbon electrode with delaminated titanium carbide MXene and multiwalled carbon nanotubes composite covered by MIP, was prepared in the work of Ozcan and coauthors [52]. On the other hand, in the work of Pereira and coauthors, an innovative paperbased platform for carrying MIP was prepared [53]. Although Ozcan and coauthors have achieved a much lower limit of detection as well as better sensitivity, the construction of Pereira and coauthor is unique in its simplicity and low cost.

The most widely used biorecognition elements were antibodies. In the work of Le and coauthors (2020), a selfassembled monolayer functionalized interdigitated chainshaped electrode with immobilized specific anti-A $\beta$ antibody was prepared for the detection of $\mathrm{A} \beta_{42}$ and used together with atypical nonfaradaic detection [54]. The selfassembled monolayer was also used in the construction of biosensors in the work of Carneiro and coauthors (2017). They modified the gold electrode by mercaptopropionic acid SAM, gold nanoparticles, and monoclonal antibody mAb DE2B4 for the analysis of $\mathrm{A} \beta_{42}$ [55]. Sethi and coauthors (2020) used a screen-printed electrode with a dual layer of graphene-reduce graphene oxide to immobilize the H31L21 antibody. The sensor was designed for use in the rapid detection of $\mathrm{A} \beta_{42}$ [56].

A unique biorecognition element-cellular prion protein was used in the work of Qin and coauthors (2020). A gold electrode with immobilized gold dendrite and electropolymerized poly(pyrrole-3-carboxylic acid) was used as a carrier for this bioreceptor for the detection of $\mathrm{A} \beta$ oligomers [57]. A comparison of the detection limits, linear concentration ranges, or detection techniques of biosensors described above is shown in Table 3. 
TABLE 3: Overview of electrochemical biosensors for the detection of $\mathrm{A} \beta$ in $\mathrm{AD}$ diagnosis.

\begin{tabular}{|c|c|c|c|c|c|}
\hline Marker & Construction & $\begin{array}{c}\mathrm{LOD} / \\
\mathrm{pM}\end{array}$ & $\begin{array}{c}\text { Liner range/ } \\
\mathrm{pM}\end{array}$ & Detection & References \\
\hline $\mathrm{A} \beta_{42}$ & Fern leaves-like gold nanostructure with an RNA aptamer & $\begin{array}{l}88.6 \\
10^{-3}\end{array}$ & $0.440-285$ & DPV & {$[51]$} \\
\hline $\mathrm{A} \beta \mathrm{O}$ & $\begin{array}{c}\text { PPy-3-COOH electropolymerized onto gold dendrite with bounded } \\
\text { cellular prion protein }\end{array}$ & $110^{-6}$ & $10^{-6}-1010^{3}$ & Impedimetry & {$[57]$} \\
\hline $\mathrm{A} \beta_{42}$ & $\begin{array}{l}\text { SAM functionalized interdigitated chain-shaped electrode with anti- } \\
\qquad \mathrm{A} \beta \text { antibody }\end{array}$ & 1.70 & $2.20-2.2010^{3}$ & $\begin{array}{l}\text { Nonfaradaic } \\
\text { detection }\end{array}$ & {$[54]$} \\
\hline $\mathrm{A} \beta_{42}$ & $\begin{array}{l}\text { GCE with titanium carbide MXene and MWCN composite including } \\
\text { MIP }\end{array}$ & $\begin{array}{l}6.65 \\
10^{-5}\end{array}$ & $\begin{array}{c}2.2010^{-4}-2.20 \\
10^{-2}\end{array}$ & DPV & {$[52]$} \\
\hline $\mathrm{A} \beta_{42}$ & $\begin{array}{c}\text { Dual layer of graphene and rGO with immobilized H31L21 antibody } \\
\text { achieved via Pyr-NHS }\end{array}$ & 2.40 & $11.0-55.010^{3}$ & DPV & {$[56]$} \\
\hline $\mathrm{A} \beta_{42}$ & MIP in a paper-based platform on the carbon ink electrode's surface & 14.8 & $22.0-22.010^{4}$ & SWV & {$[53]$} \\
\hline $\mathrm{A} \beta_{42}$ & $\begin{array}{l}\text { Gold electrode with mercaptopropionic acid SAM, gold } \\
\text { nanoparticles, and monoclonal antibody mAb DE2B4 }\end{array}$ & 1.15 & $2.20-2.2010^{2}$ & SWV & {$[55]$} \\
\hline
\end{tabular}

LOD: limit of detection, DPV: differential pulse voltammetry, A $\beta \mathrm{O}: \mathrm{A} \beta$ oligomers, PPy-3-COOH: poly(pyrrole-3-carboxylic acid), SAM: self-assembled monolayer, GCE: glassy carbon electrode, MWCN: multiwalled carbon nanotubes, MIP: molecularly imprinted polymers, rGO: reduced graphene oxide, PyrNHS: 1-pyrenebutyric acid N-hydroxysuccinimide ester, and SWV: square wave voltammetry.

5.2. Detection of tau Protein. Recent approaches in electrochemical biosensors for tau protein detection were based on antibody biorecognition elements. Different types of tau isoforms are known. Tau-441 was detected in the work of Carlin and Martic-Milne (2018), Karaboga and Sezginturk (2020), and Wang and coauthors (2017) [58-60]. In the firstmentioned paper, a very simple constriction of gold electrode covered by anti-tau antibodies was designed [58]. The paper of Karaboga and Sezginturk introduced a more complicated construction of indium tin oxide electrode coated by polyethylene terephthalate and utilizing nanocomposite of reduced graphene oxide and gold nanoparticles for antibodies binding [59]. Wang and coauthors prepared a four-electrode system of gold microband electrodes covered with a layer of a self-assembled monolayer and protein G. Protein $G$ is used to interact with immobilized antibodies to ensure their optimal orientation [60]. The fact is that the use of a nanocomposite structure in biosensor construction highly increases the sensitivity of the sensor, according to the available limit of detections.

The tau-381 isoform was determined in the work of Shui and coauthors (2018). In this paper, a combination of antibodies and aptamer as biorecognition elements was used in Sandwich assay construction. The gold working electrode was used as a carrier of cysteamine-stabilized AuNPs covered by biorecognition elements [61].

T-tau protein was determined by a gold electrode coated with a self-assembled monolayer of 3-mercaptopropionic acid with immobilized anti-T-tau antibodies in the work of Dai and coauthors (2017) and a screen-printed carbon electrode with gold nanoparticles-poly(amidoamine) dendrimer nanocomposite and anti-tau capture antibody for tau protein detection was designed in work of Razzino and coauthors (2020) [62,63]. Further details on the described electrochemical biosensors for the detection of tau protein are summarized in Table 4.

5.3. Detection of Neurotransmitters. Chemical compounds that serve as biological messengers from a nerve cell through a synapse to a target cell are called neurotransmitters. In recent years, various neurotransmitters have been measured for early diagnosis of $\mathrm{AD}$.

Electrochemical biosensors for acetylcholine detection were designed by da Silva and Brett (2020), Chauhan and coauthors (2017), and Moreira and coauthors (2017), and all of these sensors contained the enzyme acetylcholinesterase as biorecognition element [64-66]. The most sensitive one, glass plate modified by iron oxide nanoparticles-poly $(3,4-$ ethylenedioxythiophene)-reduced graphene oxide nanocomposite with immobilized enzymes acetylcholinesterase and choline oxidase, was constructed by the team of Chauhan and coauthors [65]. Moreira and coauthors prepared a biosensor based on platinum wire covered by a highly porous gold film and enzyme acetylcholinesterase, and it shows the lowest limit of detection [66]. The biosensor prepared by da Silva and Brett was based on a glassy carbon electrode modified by iron oxide nanoparticles covered by a film of poly(neural red), and acetylcholinesterase was immobilized onto its surface [64].

Another neurotransmitter, dopamine, was the target of a biosensor construction designed by Shin and coauthors (2017) and Yi and coauthors (2017). Both biosensors were enzymeless, the first one based on indium tin oxide electrode covered by graphene oxide and silver nanoparticles, and the second one based on self-supporting nanoporous gold wire with palladium nanoparticles $[67,68]$. Both sensors showed similar detection limits and so similar sensitivity.

The papers of Hughes and coauthors (2015) and Alves and coauthors (2016) were focused on the determination of glutamate by electrochemical biosensors $[69,70]$. The enzymatic sensor was based on a screen-printed carbon electrode covered by a layer of chitosan with multiwalled carbon nanotubes and the enzyme glutamate dehydrogenase and its cofactor nicotinamide adenine dinucleotide [69]. The nonenzymatic sensor was based on a graphite electrode with an immobilized small protein-like chain designed to mimic a peptide that recognizes glutamate [70]. Electrochemical biosensors for the detection of neurotransmitters are listed in Table 5. 
TABLE 4: Overview of electrochemical biosensors for tau protein detection in AD diagnosis.

\begin{tabular}{|c|c|c|c|c|c|}
\hline Marker & Construction & $\begin{array}{c}\mathrm{LOD} / \\
\mathrm{pM}\end{array}$ & $\begin{array}{c}\text { Liner range/ } \\
\mathrm{pM}\end{array}$ & Detection & Reference \\
\hline Tau-441 & Anti-tau antibodies immobilized onto a gold electrode & $10^{6}-10^{3}$ & - & CV, SWV & [58] \\
\hline T-tau & SAM of MPA binding anti-T-tau antibody on the gold electrode & - & - & DPV & [62] \\
\hline Tau-381 & $\begin{array}{l}\text { Cysteamine-stabilized AuNPs with anti-tau antibody and an aptamer } \\
\text { specific to tau-381 }\end{array}$ & 0.420 & $0.500-1.0010^{2}$ & DPV & [61] \\
\hline Tau & $\begin{array}{l}\text { SPCE modified with an AuNPs-PAMAM dendrimer nanocomposite } \\
\text { and anti-tau capture antibody }\end{array}$ & 0.030 & $0.110-91.0$ & Amperometry & [63] \\
\hline Tau-441 & $\begin{array}{l}\text { ITO-coated PET electrode with rGO-AuNPs nanocomposite and } \\
\text { anti-tau antibodies }\end{array}$ & 0.002 & $2.2010^{-2}-10.9$ & EIS, CV & [59] \\
\hline $\begin{array}{l}\text { Tau-441 } \\
\text { (2N4R) }\end{array}$ & $\begin{array}{l}\text { Four gold microband electrodes with a layer of a SAM, protein G, and } \\
\text { anti-tau antibodies }\end{array}$ & 0.030 & - & CV, EIS & [60] \\
\hline
\end{tabular}

LOD: limit of detection, CV: cyclic voltammetry, SWV: square wave voltammetry, SAM: self-assembled monolayer, MPA: 3-mercaptopropionic acid, DPV: differential pulse voltammetry, AuNPs: gold nanoparticles, SPCEs: screen-printed carbon electrode, PAMAM: poly(amidoamine), rGO: reduced graphene oxide, ITO: indium tin oxide, PET: polyethylene terephthalate, and EIS: electrochemical impedance spectroscopy.

TABLE 5: Overview of electrochemical biosensors for the detection of neurotransmitters in AD diagnosis.

\begin{tabular}{|c|c|c|c|c|c|}
\hline Marker & Construction & $\begin{array}{c}\mathrm{LOD} / \\
\mu \mathrm{M}\end{array}$ & Liner range $/ \mu \mathrm{M}$ & Detection & Reference \\
\hline $\mathrm{ACh}$ & $\begin{array}{l}\text { GCE modified by IONPs with poly(neutral red) film } \\
\text { and AChE }\end{array}$ & 1.00 & $2.50-60.0$ & Amperometry & {$[64]$} \\
\hline $\mathrm{ACh}$ & $\begin{array}{l}\text { Glass plate with IONPs-PEDOT-rGO nanocomposite } \\
\text { modified by FTO and immobilized AChE and ChO }\end{array}$ & $\begin{array}{l}4.00 \\
10^{-3}\end{array}$ & $4.0010^{-3}-8.0010^{2}$ & $\mathrm{CV}$ & {$[65]$} \\
\hline $\mathrm{ACh}$ & $\begin{array}{l}\text { Pt wire covered by highly porous gold film with } \\
\text { immobilized AChE }\end{array}$ & 10.0 & $\begin{array}{c}0.25010^{3}-1.9010^{3}(\mathrm{PBS}) \\
0.12010^{3}-1.4010^{3}(\mathrm{~GB})\end{array}$ & LSV, SWV, CA & {$[66]$} \\
\hline Dopamine & ITO electrode covered by GO and SNPs & 0.200 & $0.100-1.0010^{2}$ & $\begin{array}{l}\mathrm{CV}, \mathrm{DPV} \\
\text { amperometry }\end{array}$ & {$[67]$} \\
\hline Dopamine & Self-supporting NPG wire with PdNPs & $\begin{array}{c}\text { Up to } \\
1.00\end{array}$ & $1-2.2010^{2}$ & DPV & {$[68]$} \\
\hline Glutamate & $\begin{array}{l}\text { SPCE with chitosan and MWCN encapsulating GLDH } \\
\text { and } \mathrm{NAD}^{+}\end{array}$ & 3.00 & $7.50-105$ & Amperometry & [69] \\
\hline Glutamate & $\begin{array}{l}\text { Graphite electrode with mimetic peptide recognizing } \\
\text { glutamate }\end{array}$ & 0.001 & $1.0010^{3}-10.010^{3}$ & DPV & {$[70]$} \\
\hline
\end{tabular}

LOD: limit of detection, ACh: acetylcholine, GCE: glassy carbon electrode, IONPs: iron oxide (Fe2O3) nanoparticles, AChE: acetylcholinesterase, PEDOT: poly(3,4-ethylenedioxythiophene), rGO: reduced graphene oxide, FTO: fluorine-doped tin oxide, ChO: choline oxidase, CV: cyclic voltammetry, PBS: phosphate-buffered solution, GB: glycine buffer, LSV: linear sweep voltammetry, SWV: square wave voltammetry, CA: chronoamperometry, ITO: indium tin oxide, GO: graphene oxide, SNPs: silver nanoparticles, DPV: differential pulse voltammetry, NPG: nanoporous gold, PdNPs: palladium nanoparticles, SPCE: screen-printed carbon electrode, MWCNTs: multiwalled carbon nanotubes, GLDH: glutamate dehydrogenase, and NAD+: nicotinamide adenine dinucleotide.

5.4. Detection of Genetic and Protein Markers. MicroRNA has become a highly determined biomarker of AD. Four works focusing on the detection of microRNA-137, microRNA-146a, and microRNA-34a are described lower. Azimzadeh and coauthors (2017) designed an electrochemical biosensor for the detection of microRNA-137 based on screen-printed carbon electrodes modified by reduced graphene oxide-gold nanowire nanocomposite, and doxorubicin was immobilized as an intercalated label [71]. A gold electrode with self-assembled capture microRNA for bioconjugation with microRNA-146a was constructed by Khalilzadeh and coauthors (2019) [72]. Detection of microRNA-34a was the aim of two studies performed by two teams from Ege University. An older study described the preparation of pencil graphite electrodes with a DNA probe for microRNA-34a [73]. The second article described impedimetric biosensor based on screen-printed carbon electrode with immobilized 3.5 poly(amidoamine) dendrimer and DNA probe for microRNA-34a, and it showed better sensitivity than voltammetric biosensor [74].

APOE is encoded by a gene having three isoforms (E2, E3, and E4) [75]. APOE4 is considered a risk factor for the development of AD [7]. Mutations of APOE can be detected by genosensors, and the protein itself can be detected mainly by immunosensors. Jafari and coauthors (2019) designed genosensor based on a glassy carbon electrode with an immobilized reduced graphene oxide-cerium oxide nanoparticles nanocomposite modified by ssDNA probe for APOE gene, namely, for 23-base oligonucleotide sequences with a point mutation [75]. On the other hand, Liu and coauthors (2020) prepared an immunosensor based on a glassy carbon electrode with gold nanobipyramid coated platinum nanostructure coated by anti-APOE4 antibody and gold:palladium-polydopamine nanotube nanozyme [76].

An electrochemical biosensor for another protein biomarker of $\mathrm{AD}$, clusterin, was constructed in the work of 
TABLE 6: Overview of electrochemical biosensors for the detection of genetic and protein markers in AD diagnosis.

\begin{tabular}{|c|c|c|c|c|c|}
\hline Marker & Construction & $\mathrm{LOD} / \mathrm{nM}$ & Liner range/nM & Detection & Reference \\
\hline $\operatorname{miR}-137$ & SPCE with rGO and Au nanowires and label doxorubicin & $1.7010^{-6}$ & $\begin{array}{c}5.0010^{-6}-0.750 \\
10^{-3}\end{array}$ & DPV & {$[71]$} \\
\hline miR-146a & Au electrode modified by capture miR & $10.010^{-3}$ & $\begin{array}{c}10.0 \\
10^{-3}-1.0010^{3}\end{array}$ & SWV & {$[72]$} \\
\hline $\operatorname{miR}-34 \mathrm{a}$ & SPCE with PAMAM dendrimer and DNA probe for miR-34a & 140 & $0-10.710^{2}$ & Impedimetry & {$[74]$} \\
\hline $\mathrm{miR}-34 \mathrm{a}$ & PGE with GO and miRNA-34a specific DNA probe & $10.710^{2}$ & $7.1010^{2}-5.0010^{3}$ & DPV & {$[73]$} \\
\hline $\begin{array}{l}\text { APOE } \\
\text { gene }\end{array}$ & $\begin{array}{l}\text { GCE electrode modified by rGO-CONPs nanocomposite with } \\
\text { ssDNA probe for APOE gene }\end{array}$ & $1.0010^{-6}$ & $10.010^{-6}-10.0$ & SWV & {$[75]$} \\
\hline APOE4 & $\begin{array}{l}\text { GCE modified by Au nanobipyramid coated Pt nanocomposite } \\
\text { with anti-APOE4 antibody and AuPd-PDA nanozyme }\end{array}$ & $0.45010^{-3}$ & $1.5010^{-3}-58.0$ & Amperometry & {$[76]$} \\
\hline Clusterin & SPCE with anti-clusterin antibody & $\begin{array}{l}\text { Down to } \\
3.2010^{-5}\end{array}$ & $\begin{array}{l}3.2010^{-5}-3.20 \\
10^{-3}\end{array}$ & CV, SWV & {$[77]$} \\
\hline p53 & SPCE with anti-p53 antibody & - & - & ASV & {$[78]$} \\
\hline p53 & $\begin{array}{l}\text { SPCE modified by bifunctional core-shell Au-Pt/Au NPs with } \\
\text { anti-p53 monoclonal antibody }\end{array}$ & 66.0 & - & $\mathrm{CA}$ & [79] \\
\hline
\end{tabular}

Islam and coauthors (2018). Label-free immunosensor was based on a screen-printed carbon electrode with anti-clusterin antibody fragments [77].

Electrochemical immunosensors for the detection of conformationally altered (unfolded) protein p53 have also been proposed for the early diagnosis of AD. A simple screen-printed carbon electrode with bound anti-p53 antibody was prepared by Tonello and coauthors (2016), but only preliminary results were described [78]. Iglesias-Mayor and coauthors (2020) designed an immunosensor based on bifunctional core-shell $\mathrm{Au}-\mathrm{Pt} / \mathrm{Au}$ and immobilized anti-p53 antibody. This proposal was based on competition between protein $\mathrm{p} 53$ in the sample and p53 bounded to streptavidin modified magnetic beads added in measured solution, so, the higher concentration of p53 in the sample caused the lower catalytic current response [79]. The electrochemical genoand immunosensors described above are summarized in Table 6.

\section{Perspectives in the Diagnosis of Alzheimer's Disease}

Because the number of AD patients is growing rapidly and no therapeutic drug to cure AD was found, early diagnosis is the key factor in managing and slowing the disease. The most important step for the future diagnosis of $\mathrm{AD}$ lies in early diagnosis before a severe clinical symptom appears. Preventive testing should include biomarkers that precede these symptoms $[10,80]$. This examination should be noninvasive, affordable, simple, and fast. Less invasive analysis of blood biomarkers is a promising possibility, but noninvasive analysis of urine, tears, sweat, or saliva would overcome the limitation of invasive sampling $[80,81]$. AD as a multifactorial disease with still unclear pathology is very hard to diagnose. Biosensors for simultaneous detection of multiple biomarkers would simplify and speed up diagnostics from just one sample. So, the important strategy is to integrate more analytical technologies into one platform. The use of nanotechnologies would provide high sensitivity and specificity of biosensors providing analysis of very low concentrations of biomarkers in noninvasively taken samples [81, 82]. Molecularly imprinted polymers allow the analysis of high-affinity aptamers and antibodies specific for AD biomarkers. This is an important challenge for the development of biosensors, which should pay close attention to this problem $[10,82]$.

Electrochemical biosensors are technology growing rapidly in the diagnosis of $\mathrm{AD}$, but the extension of tested biomarkers would facilitate their incorporation into clinical practice. Many biomarkers including metal ions or posttranslational protein modifications are still neglected. Heavy metals have been analyzed by electrochemical biosensor from water in the work of Sciuto and coauthors (2020), copper from water samples was determined in the work of Cui and coauthors (2014), and iron from the water was tested in the work of Kamal and coauthors (2014) [83-85]. Glycan electrochemical biosensor for cancer diagnosis was presented in the work of Kveton and coauthors (2019), the electrochemical behavior of phosphotyrosine was observed in the work of Popa and Duculescu (2013), and dual-mode sensor using an electrolyte-insulator-semiconductor fieldeffect device coupled with nanoplasmonic effects was developed for protein phosphorylation detection in the work of Bhalla and coauthors (2015) [86-88]. So, various electrochemical biosensors exist, but their optimization and application in $\mathrm{AD}$ diagnosis were not tried yet.

\section{Conclusion}

$\mathrm{AD}$ is a serious health and socioeconomic problem, and its solution is mainly in early and simple but precise diagnosis, so proper diagnostic techniques are required. Simple sensors suitable for point-of-care use are especially desired. Electrochemical biosensors are the future of $\mathrm{AD}$ diagnostics due to their high sensitivity, simple construction, easy handling, portability, and low cost. Although many possible diagnostic methods have recently been investigated, their integration into clinical practice and diagnostic protocol is necessary, especially since early diagnosis of $\mathrm{AD}$ is a crucial part of good treatment and patient's state outcome. Detection of blood biomarkers instead of CSF biomarkers is one of the key parts of this diagnostic protocol which could also make the 
diagnosis more accessible to all patients with or without $\mathrm{AD}$ symptoms. Although electrochemical biosensors for the detection of $\mathrm{A} \beta$, tau proteins, neurotransmitters, and genetic and protein markers have been discussed in this review, laboratory determination of $\mathrm{A} \beta 42$ alone or in combination with $\mathrm{A} \beta 40, \mathrm{P}-\mathrm{tau}_{181}$, and $\mathrm{T}$-tau has been established into practice so far. Standard laboratory methodology could be improved by analyzing a combination of the currently estimated markers along with neurotransmitters and genetic markers from blood samples, which make the test for $\mathrm{AD}$ diagnosis available to the wide public. This protocol could detect $\mathrm{AD}$ in asymptomatic patients and prolong their quality lifetime.

\section{Abbreviations}

$\begin{array}{ll}\text { AD: } & \text { Alzheimer's disease } \\ \text { A } \beta: & \text { Amyloid } \beta \\ \text { CSF: } & \text { Cerebrospinal fluid } \\ \text { FDG- } & \text { Fluorodeoxyglucose positron emission } \\ \text { PET: } & \text { tomography } \\ \text { MRI: } & \text { Magnetic resonance imagining } \\ \text { NFT: } & \text { Neurofibrillary tangles } \\ \text { PET: } & \text { Positron emission tomography } \\ \text { P-tau: } & \text { Phosphorylated tau protein } \\ \text { T-tau: } & \text { Total tau protein. }\end{array}$

\section{Data Availability}

All the data are inside the manuscript.

\section{Conflicts of Interest}

The authors declare no conflicts of interest.

\section{Acknowledgments}

A long-term organization development plan for mass destruction weapons (Faculty of Military Health Sciences, University of Defense, Czech Republic) is gratefully acknowledged.

\section{References}

[1] P. Mehrotra, "Biosensors and their applications-a review," Journal of Oral Biology and Craniofacial Research, vol. 6, no. 2, pp. 153-159, 2016.

[2] L. C. Brazaca, I. Sampaio, V. Zucolotto, and B. C. Janegitz, "Applications of biosensors in Alzheimer's disease diagnosis," Talanta, vol. 210, Article ID 120644, 2020.

[3] K. Rajpoot, "Recent advances and applications of biosensors in novel technology," Biosensors Journal, vol. 6, pp. 1-12, 2017.

[4] F. J. Gruhl, B. E. Rapp, and K. Länge, "Biosensors for diagnostic applications," in Molecular Diagnostics, H. Seitz and S. Schumacher, Eds., pp. 115-148, Springer Berlin Heidelberg, Berlin, Germany, 2013.

[5] N. Aggarwal, R. Shah, and D. Bennett, "Alzheimer's disease: unique markers for diagnosis \& new treatment modalities," Indian Journal of Medical Research, vol. 142, no. 4, pp. 369-382, 2015.
[6] B. N. Dugger and D. W. Dickson, "Pathology of neurodegenerative diseases," Cold Spring Harbor Perspectives in Biology, vol. 9, no. 7, Article ID a028035, 2017.

[7] C. Toyos-Rodríguez, F. J. García-Alonso, and A. de la Escosura-Muñiz, "Electrochemical biosensors based on nanomaterials for early detection of Alzheimer's disease," Sensors, vol. 20, no. 17, p. 4748, 2020.

[8] P. Martinkova, A. Kostelník, T. Valek, and M. Pohanka, "Main streams in the construction of biosensors and their applications," International Journal of Electrochemical Science, vol. 12, pp. 7386-7403, 2017.

[9] Z. Tavakolian-Ardakani, O. Hosu, C. Cristea, M. MazloumArdakani, and G. Marrazza, "Latest trends in electrochemical sensors for neurotransmitters: a review," Sensors, vol. 19, no. 9, p. 2037, 2019.

[10] B. Shui, D. Tao, A. Florea et al., "Biosensors for Alzheimer's disease biomarker detection: a review," Biochimie, vol. 147, pp. 13-24, 2018.

[11] V. Gaudin, "Receptor-based electrochemical biosensors for the detection of contaminants in food products," in Electrochemical Biosensors, pp. 307-365, Elsevier, Amsterdam, Netherlands, 2019.

[12] A. González-López and M. T. Fernández Abedul, "Electrochemical detection of melatonin in a flow injection analysis system," Laboratory Methods in Dynamic Electroanalysis, Elsevier, Amsterdam, Netherlands, pp. 85-97, 2020.

[13] S. Roy and S. Pandit, "Microbial electrochemical system," in Microbial Electrochemical Technology, S. V. Mohan, S. Varjani, and A. Pandey, Eds., Elsevier, Amsterdam, Netherlands, pp. 19-48, 2019.

[14] G. Hussain and D. Silvester, "Comparison of voltammetric techniques for the electroanalysis of dissolved solids and gases in water, acetonitrile and room temperature ionic liquids (RTILs): unusual behaviour for gases," in Proceedings of the PRiME 2016/230th ECS Meeting, Honolulu, HI, USA, 2016.

[15] E. Cesewski and B. N. Johnson, "Electrochemical biosensors for pathogen detection," Biosensors and Bioelectronics, vol. 159, Article ID 112214, 2020.

[16] A. Pisoschi, "Potentiometric biosensors: concept and analytical applications-an editorial," Biochemistry \& Analytical Biochemistry, vol. 5, 2016.

[17] C. Okafor, D. Grooms, E. Alocilja, and S. Bolin, "Comparison between a conductometric biosensor and ELISA in the evaluation of Johne's disease," Sensors, vol. 14, no. 10, pp. 19128-19137, 2014.

[18] J. Leva-Bueno, S. A. Peyman, and P. A. Millner, "A review on impedimetric immunosensors for pathogen and biomarker detection," Medical Microbiology and Immunology, vol. 209, no. 3, pp. 343-362, 2020.

[19] M. Hoyos-Nogués, F. J. Gil, and C. Mas-Moruno, "Antimicrobial peptides: powerful biorecognition elements to detect bacteria in biosensing technologies," Molecules, vol. 23, no. 7, 2018.

[20] WHO, "Global action plan on the public health response to dementia 2017-2025," in WHO Document Production ServicesWHO, Geneva, Switzerland, 2017.

[21] M. F. Mendez, "Early-onset Alzheimer disease," Neurologic Clinics, vol. 35, no. 2, pp. 263-281, 2017.

[22] R. H. Swerdlow, "Pathogenesis of Alzheimer's disease," Clinical Interventions in Aging, vol. 2, no. 3, pp. 347-359, 2007.

[23] A. Kas, R. Migliaccio, and B. Tavitian, "A future for PET imaging in Alzheimer's disease," European Journal of Nuclear 
Medicine and Molecular Imaging, vol. 47, no. 2, pp. 231-234, 2020.

[24] A. K. Thakur, P. Kamboj, and K. Goswami, "Pathophysiology and management of Alzheimer's disease: an overview," Journal of Analytical \& Pharmaceutical Research, vol. 7, no. 2, pp. 226-235, 2018.

[25] M. Rana and A. K. Sharma, "Cu and $\mathrm{Zn}$ interactions with $\mathrm{A} \beta$ peptides: consequence of coordination on aggregation and formation of neurotoxic soluble A $\beta$ oligomers," Metallomics, vol. 11, no. 1, pp. 64-84, 2018.

[26] F. Tahmasebinia and S. Emadi, "Effect of metal chelators on the aggregation of beta-amyloid peptides in the presence of copper and iron," Biometals, vol. 30, no. 2, pp. 285-293, 2017.

[27] A. Gella and N. Durany, "Oxidative stress in Alzheimer disease," Cell Adhesion \& Migration, vol. 3, no. 1, pp. 88-93, 2009.

[28] M.-S. García-Ayllón, I. Riba-Llena, C. Serra-Basante, J. Alom, R. Boopathy, and J. Sáez-Valero, "Altered levels of acetylcholinesterase in Alzheimer plasma," PLoS One, vol. 5, no. 1, p. e8701, 2010.

[29] J. C. Vickers, S. Mitew, A. Woodhouse et al., "Defining the earliest pathological changes of Alzheimer's disease," Current Alzheimer Research, vol. 13, no. 3, pp. 281-287, 2016.

[30] J. C. Lee, S. J. Kim, S. Hong, and Y. Kim, "Diagnosis of Alzheimer's disease utilizing amyloid and tau as fluid biomarkers," Experimental \& Molecular Medicine, vol. 51, no. 5, pp. 1-10, 2019.

[31] B. J. Kelley and R. C. Petersen, “Alzheimer's disease and mild cognitive impairment," Neurologic Clinics, vol. 25, no. 3, pp. 577-609, 2007.

[32] E. J. Mufson, L. Binder, S. E. Counts et al., "Mild cognitive impairment: pathology and mechanisms," Acta Neuropathologica, vol. 123, no. 1, pp. 13-30, 2012.

[33] T. Yamasaki, H. Muranaka, Y. Kaseda, Y. Mimori, and S. Tobimatsu, "Understanding the pathophysiology of Alzheimer's disease and mild cognitive impairment: a mini review on fMRI and ERP studies," Neurology Research International, vol. 2012, p. 719056, 2012.

[34] N. R. Barthélemy, R. J. Bateman, C. Hirtz et al., "Cerebrospinal fluid phospho-tau T217 outperforms T181 as a biomarker for the differential diagnosis of Alzheimer's disease and PET amyloid-positive patient identification," Alzheimer's Research \& Therapy, vol. 12, no. 1, p. 26, 2020.

[35] B. Olsson, R. Lautner, U. Andreasson et al., "CSF and blood biomarkers for the diagnosis of Alzheimer's disease: a systematic review and meta-analysis," The Lancet Neurology, vol. 15, no. 7, pp. 673-684, 2016.

[36] S. D. Targum, "Biomarkers for the identification and treatment of dementia," Psychiatry (Edgmont (Pa.: Township)), vol. 5, no. 2, pp. 51-56, 2008.

[37] H. Hampel, K. Blennow, L. M. Shaw, Y. C. Hoessler, H. Zetterberg, and J. Q. Trojanowski, "Total and phosphorylated tau protein as biological markers of Alzheimer's disease," Experimental Gerontology, vol. 45, no. 1, pp. 30-40, 2010.

[38] C. Wattmo, K. Blennow, and O. Hansson, "Cerebro-spinal fluid biomarker levels: phosphorylated tau (T) and total tau $(\mathrm{N})$ as markers for rate of progression in Alzheimer's disease," BMC Neurology, vol. 20, no. 1, p. 10, 2020.

[39] D. S. Strac, D. Muck-Seler, and N. Pivac, "Neurotransmitter measures in the cerebrospinal fluid of patients with Alzheimer's disease: a review," Psychiatria Danubina, vol. 27, no. 1, pp. 14-24, 2015.
[40] R. Sangubotla and J. Kim, "Recent trends in analytical approaches for detecting neurotransmitters in Alzheimer's disease," TRAC Trends in Analytical Chemistry, vol. 105, pp. 240-250, 2018.

[41] J. Toombs and H. Zetterberg, "In the blood: biomarkers for amyloid pathology and neurodegeneration in Alzheimer's disease," Brain Communications, vol. 2, no. 1, 2020.

[42] S. Janelidze, E. Stomrud, S. Palmqvist et al., "Plasma $\beta$-amyloid in Alzheimer's disease and vascular disease," Scientific Reports, vol. 6, no. 1, p. 26801, 2016.

[43] A. Nakamura, N. Kaneko, V. L. Villemagne et al., "High performance plasma amyloid- $\beta$ biomarkers for Alzheimer's disease," Nature, vol. 554, no. 7691, pp. 249-254, 2018.

[44] V. Ovod, K. N. Ramsey, K. G. Mawuenyega et al., “Amyloid $\beta$ concentrations and stable isotope labeling kinetics of human plasma specific to central nervous system amyloidosis," Alzheimer's and Dementia, vol. 13, no. 8, pp. 841-849, 2017.

[45] H. Zetterberg and S. C. Burnham, "Blood-based molecular biomarkers for Alzheimer's disease," Molecular Brain, vol. 12, no. 1, p. 26, 2019.

[46] O. Amor-Gutiérrez, E. Costa-Rama, N. Arce-Varas et al., "Competitive electrochemical immunosensor for the detection of unfolded p53 protein in blood as biomarker for Alzheimer's disease," Analytica Chimica Acta, vol. 1093, pp. 28-34, 2020.

[47] C. Lanni, M. Racchi, G. Mazzini et al., "Conformationally altered p53: a novel Alzheimer's disease marker?" Molecular Psychiatry, vol. 13, no. 6, pp. 641-647, 2008.

[48] K. S. Nahan, K. B. Walsh, O. Adeoye, and J. A. LanderoFigueroa, "The metal and metalloprotein profile of human plasma as biomarkers for stroke diagnosis," Journal of Trace Elements in Medicine \& Biology, vol. 42, pp. 81-91, 2017.

[49] J. Xu, S. J. Church, S. Patassini et al., "Plasma metals as potential biomarkers in dementia: a case-control study in patients with sporadic Alzheimer's disease," Biometals, vol. 31, no. 2, pp. 267-276, 2018.

[50] C. Guan, R. Dang, Y. Cui et al., "Characterization of plasma metal profiles in Alzheimer's disease using multivariate statistical analysis," PLoS One, vol. 12, no. 7, Article ID e0178271, 2017.

[51] M. Negahdary and H. Heli, “An ultrasensitive electrochemical aptasensor for early diagnosis of Alzheimer's disease, using a fern leaves-like gold nanostructure," Talanta, vol. 198, pp. 510-517, 2019.

[52] N. Özcan, O. Akyıldırım, N. Atar, M. L. Yola, and M. L. au, "Electrochemical detection of amyloid- $\beta$ protein by delaminated titanium carbide MXene/multi-walled carbon nanotubes composite with molecularly imprinted polymer," Materials Today Communications, vol. 23, p. 101097, 2020.

[53] M. V. Pereira, A. C. Marques, D. Oliveira et al., "Paper-based platform with an in situ molecularly imprinted polymer for $\beta$-amyloid," ACS Omega, vol. 5, no. 21, pp. 12057-12066, 2020.

[54] H. T. N. Le, J. Park, and S. Cho, "A probeless capacitive biosensor for direct detection of amyloid beta 1-42 in human serum based on an interdigitated chain-shaped electrode," Micromachines, vol. 11, no. 9, 2020.

[55] P. Carneiro, J. Loureiro, C. Delerue-Matos, S. Morais, and M. do Carmo Pereira, “Alzheimer's disease: development of a sensitive label-free electrochemical immunosensor for detection of amyloid beta peptide," Sensors and Actuators B: Chemical, vol. 239, pp. 157-165, 2017.

[56] J. Sethi, M. Van Bulck, A. Suhail, M. Safarzadeh, A. PerezCastillo, and G. Pan, "A label-free biosensor based on 
graphene and reduced graphene oxide dual-layer for electrochemical determination of beta-amyloid biomarkers," Microchimica Acta, vol. 187, no. 5, p. 288, 2020.

[57] J. Qin, S. Kim, M. Cho, and Y. Lee, "Hierarchical and ultrasensitive amyloid beta oligomer sensor for practical applications," Chemical Engineering Journal, vol. 401, Article ID 126055, 2020.

[58] N. Carlin and S. Martic-Milne, "Anti-tau antibodies based electrochemical sensor for detection of tau protein biomarkers," Journal of the Electrochemical Society, vol. 165, no. 12, pp. G3018-G3025, 2018.

[59] M. N. Sonuç Karaboga and M. K. Sezgintürk, "Analysis of tau441 protein in clinical samples using $\mathrm{rGO} / \mathrm{AuNP}$ nanocomposite-supported disposable impedimetric neuro-biosensing platform: towards Alzheimer's disease detection," Talanta, vol. 219, Article ID 121257, 2020.

[60] S. X. Wang, D. Acha, A. J. Shah et al., "Detection of the tau protein in human serum by a sensitive four-electrode electrochemical biosensor," Biosensors and Bioelectronics, vol. 92, pp. 482-488, 2017.

[61] B. Shui, D. Tao, J. Cheng, Y. Mei, N. Jaffrezic-Renault, and Z. Guo, "A novel electrochemical aptamer-antibody sandwich assay for the detection of tau-381 in human serum," The Analyst, vol. 143, no. 15, pp. 3549-3554, 2018.

[62] Y. Dai, A. Molazemhosseini, and C. C. Liu, "A single-use, in vitro biosensor for the detection of $\mathrm{t}$-tau protein, a biomarker of neuro-degenerative disorders, in PBS and human serum using differential pulse voltammetry (DPV)," Biosensors, vol. 7, no. 1, 2017.

[63] C. A. Razzino, V. Serafín, M. Gamella et al., "An electrochemical immunosensor using gold nanoparticles-PAMAMnanostructured screen-printed carbon electrodes for tau protein determination in plasma and brain tissues from Alzheimer patients," Biosensors and Bioelectronics, vol. 163, Article ID 112238, 2020.

[64] W. da Silva and C. M. A. Brett, "Novel biosensor for acetylcholine based on acetylcholinesterase/poly(neutral red)deep eutectic solvent $/ \mathrm{Fe}_{2} \mathrm{O}_{3}$ nanoparticle modified electrode," Journal of Electroanalytical Chemistry, vol. 872, Article ID 114050, 2020.

[65] N. Chauhan, S. Chawla, C. S. Pundir, and U. Jain, "An electrochemical sensor for detection of neurotransmitteracetylcholine using metal nanoparticles, 2D material and conducting polymer modified electrode," Biosensors and Bioelectronics, vol. 89, no. 1, pp. 377-383, 2017.

[66] F. T. C. Moreira, M. G. F. Sale, and M. Di Lorenzo, “Towards timely Alzheimer diagnosis: a self-powered amperometric biosensor for the neurotransmitter acetylcholine," Biosensors and Bioelectronics, vol. 87, pp. 607-614, 2017.

[67] J. W. Shin, K. J. Kim, J. Yoon, J. Jo, W. A. El-Said, and J. W. Choi, "Silver nanoparticle modified electrode covered by graphene oxide for the enhanced electrochemical detection of dopamine," Sensors, vol. 17, no. 12, 2017.

[68] X. Yi, Y. Wu, G. Tan, P. Yu, L. Zhou, and Z. Zhou, J. Chen, Z. Wang, J. Pang, and C. Ning, Palladium nanoparticles entrapped in a self-supporting nanoporous gold wire as sensitive dopamine biosensor," Scientific Reports, vol. 7, no. 1, p. 7941, 2017.

[69] G. Hughes, R. M. Pemberton, P. R. Fielden, and J. P. Hart, "Development of a novel reagentless, screen-printed amperometric biosensor based on glutamate dehydrogenase and $\mathrm{NAD}^{+}$, integrated with multi-walled carbon nanotubes for the determination of glutamate in food and clinical applications,"
Sensors and Actuators B: Chemical, vol. 216, pp. 614-621, 2015.

[70] L. Alves, A. Castro, S. Oliveira et al., "Development of a mimetic system for electrochemical detection of glutamate," Journal of Solid State Electrochemistry, vol. 20, 2016.

[71] M. Azimzadeh, N. Nasirizadeh, M. Rahaie, and H. NaderiManesh, "Early detection of Alzheimer's disease using a biosensor based on electrochemically-reduced graphene oxide and gold nanowires for the quantification of serum microRNA-137," RSC Advances, vol. 7, no. 88, pp. 55709-55719, 2017.

[72] B. Khalilzadeh, M. Rashidi, A. Soleimanian et al., "Development of a reliable microRNA based electrochemical genosensor for monitoring of mir-146a, as key regulatory agent of neurodegenerative disease," International Journal of Biological Macromolecules, vol. 134, pp. 695-703, 2019.

[73] D. Isin, E. Eksin, and A. Erdem, "Graphene oxide modified single-use electrodes and their application for voltammetric miRNA analysis," Materials Science and Engineering: $C$, vol. 75, pp. 1242-1249, 2017.

[74] G. Congur and A. Erdem, "PAMAM dendrimer modified screen printed electrodes for impedimetric detection of miRNA-34a," Microchemical Journal, vol. 148, pp. 748-758, 2019.

[75] S. Jafari, F. Faridbod, and H. Haji-Hashemi, "An electrochemical genosensor for a fragment of apolipoprotein e gene based on reduced graphene and cerium oxide nanocomposite," Analytical \& Bioanalytical Electrochemistry, vol. 11, pp. 1625-1637, 2019.

[76] Y. Liu, G. He, H. Liu et al., "Electrochemical immunosensor based on AuBP@pt nanostructure and AuPD-PDA nanozyme for ultrasensitive detection of APOE4," RSC Advances, vol. 10, no. 13, pp. 7912-7917, 2020.

[77] K. Islam, S. Damiati, J. Sethi, A. Suhail, and G. Pan, "Development of a label-free immunosensor for clusterin detection as an Alzheimer's biomarker," Sensors, vol. 18, no. 1, 2018.

[78] S. Tonello, M. Serpelloni, N. F. Lopomo, G. Abate, D. L. Uberti, and E. Sardini, "Screen-printed biosensors for the early detection of biomarkers related to Alzheimer disease: preliminary results," Procedia Engineering, vol. 168, pp. 147150, 2016.

[79] A. Iglesias-Mayor, O. Amor-Gutiérrez, A. Novelli, M.-T. Fernández-Sánchez, A. Costa-García, and A. de la Escosura-Muñiz, “Bifunctional Au@Pt/Au core@shell nanoparticles as novel electrocatalytic tags in immunosensing: application for Alzheimer's disease biomarker detection," Analytical Chemistry, vol. 92, no. 10, pp. 7209-7217, 2020.

[80] H. P. Karki, Y. Jang, J. Jung, and J. Oh, "Correction to: advances in the development paradigm of biosample-based biosensors for early ultrasensitive detection of Alzheimer's disease," Journal of Nanobiotechnology, vol. 19, no. 1, p. 118, 2021.

[81] E. Mikuła, "Recent advancements in electrochemical biosensors for Alzheimer's disease biomarkers detection," Current Medicinal Chemistry, vol. 28, no. 20, 2021.

[82] D. Gopalan, A. Pandey, A. T. Alex et al., "Nanoconstructs as a versatile tool for detection and diagnosis of Alzheimer biomarkers," Nanotechnology, vol. 32, no. 14, Article ID 142002, 2021.

[83] E. L. Sciuto, S. Petralia, J. R. Meer, and S. Conoci, "Miniaturized electrochemical biosensor based on whole-cell for heavy metal ions detection in water," Biotechnology and Bioengineering, vol. 118, no. 4, pp. 1456-1465, 2021. 
[84] L. Cui, J. Wu, J. Li, Y. Ge, and H. Ju, "Electrochemical detection of $\mathrm{Cu}^{2+}$ through ag nanoparticle assembly regulated by copper-catalyzed oxidation of cysteamine," Biosensors and Bioelectronics, vol. 55, pp. 272-277, 2014.

[85] A. Kamal, N. Sharma, V. Bhalla, M. Kumar, and R. K. Mahajan, "Electrochemical sensing of iron (III) by using rhodamine dimer as an electroactive material," Talanta, vol. 128, pp. 422-427, 2014.

[86] F. Kveton, A. Blsakova, L. Lorencova et al., "A graphene-based glycan biosensor for electrochemical label-free detection of a tumor-associated antibody," Sensors, vol. 19, no. 24, 2019.

[87] O. M. Popa and V. C. Diculescu, "Electrochemical oxidation mechanism of phosphotyrosine at a glassy carbon electrode," Journal of Electroanalytical Chemistry, vol. 689, pp. 216-222, 2013.

[88] N. Bhalla, M. Di Lorenzo, G. Pula, and P. Estrela, "Protein phosphorylation detection using dual-mode field-effect devices and nanoplasmonic sensors," Scientific Reports, vol. 5, no. 1, p. 8687, 2015. 